\title{
ANALISIS FAKTOR-FAKTOR WORK FROM HOME UNTUK MENILAI KINERJA KARYAWAN ASTRA CREDIT COMPANIES BEKASI PANDEMI COVID-19
}

\section{Julio Immanuel}

Universitas Kristen Satya Wacana, Jawa Tengah, Indoensia

Email:212017248@student.uksw.edu

\begin{tabular}{|c|c|}
\hline INFO ARTIKEL & ABSTRAK \\
\hline $\begin{array}{l}\text { Diterima } \\
28 \text { November } 2021\end{array}$ & $\begin{array}{l}\text { Tujuan dari penelitian ini adalah untuk menganalisis tentang faktor- } \\
\text { faktor bekerja dari rumah (Work From Home) untuk menilai kinerja }\end{array}$ \\
\hline Direvisi & karyawan selama pandemi COVID-19 pada \\
\hline 15 Desember 2021 & Metode penelitian yang digunakan dalam penelitian ini adalah \\
\hline Disetujui & metode kualitatif deskriptif. Jenis data yang digunakan dalam \\
\hline 21 Desember 2021 & penelitian ini adalah data kualitatif. Dalam penelitian ini narasumber \\
\hline Kata Kunci: & yang digunakan sebanyak 5 orang karyawan Astra Credit Companies \\
\hline Kinerja; work from & (ACC). Hasil dari penelitian ini adalah work from home membuat \\
\hline home; covid-19 & $\begin{array}{l}\text { karyawan lebih fleksibel dalam melakukan pekerjaannya serta dapat } \\
\text { memberikan solusi untuk menghemat biaya operasional serta } \\
\text { membatasi penyebaran Virus Covid- } 19 \text { melalui Social Distancing. }\end{array}$ \\
\hline
\end{tabular}

\section{ABSTRACT}

The purpose of this study is to analyze the factors of working from home (Work From Home) to assess employee performance during the COVID-19 pandemic in finance companies. The research method used in this research is descriptive qualitative method. The type of data used in this research is qualitative data. In this study, 5 employees of Astra Keywords: $\quad C r e d i t$ Companies (ACC) were used as resource persons. The results of Performance; work this study are that work from home makes employees more flexible in from home; covid- doing their jobs andcan provide solutions to save operational costs 19 and limit the spread of the Covid-19 Virus through Social Distancing.

\section{Pendahuluan}

Pada akhir tahun 2019 hingga awal tahun 2020 Badan World Health Organization menetapkan bahwa Coronavirus Disease - 19 (COVID-19) telah menjadi permasalahan dunia. WHO berpendapat bukan hanya permasalahan dibidang kesehatan, melainkan permasalahan ke dalam bidang ekonomi, sosial, politik. Konsekuensi yang ditimbulkan bukan hanya menjadi permasalahan setiap individu saja melainkan menjadi tanggung jawab bersama untuk mencegah penyebaran Covid-19.

Salah satu upaya untuk mengurangi penyebaran Covid-19 adalah pembatasan aktivitas di luar rumah (Wahyu \& Saâ, 2020). Pembatasan tersebut diwajibkan untuk sebagian pekerja melakukan pekerjaannya dari rumah atau kerja dari rumah / work from home (WFH). Work From Home merupakan pekerjaan berbayar yang bisa dilakukan dari jarak jauh, biasanya lebih banyak dilakukan dari rumah (Crosbie \& Moore, 2004). Meskipun demikian, masih ada beberapa pekerjaan yang belum bisa menerapkan work from home sehingga diwajibkan untuk bekerja di luar rumah. Di Indonesia, bekerja dari rumah diinstruksikan Presiden pada 15 Maret 2020, bersamaan dengan tersebar pandemi

$\begin{array}{ll}\text { How to cite: } & \text { Immanuel, J. (2022). Analisis Faktor-Faktor Work From Home untuk Menilai Kinerja Karyawan } \\ & \text { Astra Credit Companies Bekasi Pandemi Covid-19, Jurnal Syntax Transformation, 3(1). } \\ & \text { https://doi.org/10.46799/jst.v3i1.496 } \\ \text { E-ISSN: } & 2721-2769 \\ \text { Published by: } & \text { Ridwan Institute }\end{array}$


COVID-19 di Indonesia (Putri \& Jumadi, 2020)

Menurut (Pristiyono et al., 2020) konsep work from home adalah konsep dimana karyawan dapat melakukan pekerjaannya dari rumah. Setiap perusahaan pasti mempunyai tujuan yang berbeda antara suatu perusahaan dengan perusahaan yang lainnya. untuk mencapai tujuan tersebut, banyak berbagai faktor yang terlibat dalam pencapaian tersebut. Dalam hal ini adalah faktor yang paling berpengaruh penting adalah sumber daya manusia. Bekerja selama pandemi tentu memberikan perubahan dalam kultur kerja yang membuat pekerja perlu melakukan penyesuaian. Sebelum diberlakukannya work from home era pandemi, sebagian besar pekerjaan dilakukan menggunakan interaksi tatap muka, termasuk ketika melakukan kolaborasi maupun bekerja dengan tim. Di sisi lain, pekerjaan dan kehidupan rumah adalah suatu hal yang terpisah. Sebab, bekerja memerlukan waktu dan suasana khusus, terlebih ketika akan bertemu dengan rekan kerja profional (January, 2020). Akan tetapi, pandemi mampu mengubah kultur bekerja yang sebelumnya sulit untuk diubah. Perubahan dari dampak work from home yang paling menonjol adalah fleksibilitas jam kerja dan individu juga dapat menentukan area kerja yang didesain sendiri sehingga memberikan kenyamanan dalam melakukan pekerjaannya di rumah. Walaupun pandemi Covid-19 terasa di kehidupan sehari-hari yang semua orang sudah terbiasa dan mahir menggunakan teknologi namun dalam pelaksanaan work from home masih ditemukan beberapa kendala dan proses adaptasi yang masih dibutuhkan. Tantangan-tantangan yang dihadapi perusahaan datang setelah diberlakukannya work from home. Oleh sebab itu, menjaga kedisiplinan dan produktivitas merupakan hal yang mutlak dan wajib selama work from home. Sama seperti para karyawan, saat melaksanakan work from home terdapat beberapa kendala seperti batasan waktu yang dan komunikasi antar tim kurang maksimal. Untuk menunjukkannya para sumber daya manusia tersebut harus mampu menunjukkan kemampuan yang dimiliki kepada perusahaan.

Menurut (Fadrianti \& Darmawan, 2018) kinerja adalah hasil kerja yang dapat dicapai oleh seseorang atau kelompok dalam suatu organisasi sesuai dengan wewenang dan tanggung jawab masing-masing, dalam rangka upaya mencapai tujuan organisasi bersangkutan secara legal, tidak melawan hukum, moral dan sesuai dengan etika. Menurut (Kelvyn et al., 2021) bahwa kinerja berasal dari kata job performance atau performance (prestasi kerja atau prestasi sesungguhnya yang dicapai oleh seseorang). Kinerja dapat diartikan sebagai hasil kerja secara kualitas dan kuantitas yang dicapai oleh pegawai dalam melaksanakan tugasnya sesuai dengan tanggung jawab yang diberikan kepadanya.

Kinerja merupakan hasil yang dicapai oleh karyawan dalam melakukan tugas dan tanggung jawab sesuai dengan Standar Operasional Prosedur (SOP) masing-masing di setiap perusahaan atau organisasi. Pada dasarnya, kinerja karyawan dapat dilihat dari kualitas kerja, kuantitas kerja dan ketepatan waktu karyawan tersebut dalam bekerja (Nugraheni et al., 2014). Perusahaan yang mempunyai kinerja yang baik, akan lebih mudah untuk mencapai tujuan. Alasan kemudahan dalam mencapai tujuan adalah perusahaan tersebut akan dapat bekerja sama dengan karyawannya secapa optimal. Kinerja karyawan dapat memicu persaingan suatu perusahaan dengan perusahaan lainnya.

Berdasarkan latar belakang yang telah dipaparkan oleh penulis maka penelitian ini akan dilakukan terhadap karyawan Astra Credit Companies apakah terdapat faktorfaktor yang dapat mempengaruhi kinerja pada karyawan. 
Berdasarkan permasalahan diatas yang telah tersebut sebelumnya, maka permasalahan yang akan dijawab dalam penelitian ini adalah sebagai berikut: Pertama, bagaimana perbedaan kinerja pada saat sebelum Covid-19 dan sesudah Covid-19?; kedua, apakah work from home efektif bagi karyawan?; ketiga, apakah work from home dapat merubah produktivitas pada karyawan? Dengan demikian tujuan penelitian ini adalah memberi manfaat secara teoritis terutama dalam bekerja dari rumah semasa pandemi dan juga diharapkan dalam hasil penelitian ini menjadi masukkan dan pembelajaran kepada karyawan untuk mendorong semangat bekerja di tengah-tengah pandemi Covid-19.

\section{Metode Penelitian}

Pada penelitian ini menggunakan metode penelitian kualitatif (Darmalaksana, 2020). Tujuan penggunaan metode kualitatif adalah untuk dapat lebih memahami dan menggambarkan karakter narasumber secara mendalam dalam kaitannya dengan faktorfaktor work from home untuk menilai kinerja karyawan. Metode penelitian kualitatif adalah metode penelitian yang digunakan untuk meneliti objek yang bersifat alamiah, dimana peneliti dalam hal ini merupakan instrumen kunci dari penelitian tersebut. Menurut (Pradiani, 2017). Metode penelitian kualitatif adalah penelitian yang menghasilkan data deskriptif berupa kata-kata lisan dari orang- orang yang dapat diamati oleh peneliti. Menurut (Hartono \& Rahadi, 2021) penelitian kualitatif merupakan studi yang menggunakan dan mengumpulkan beragam studi kasus bahan empiris, pengalaman pribadi, introspektif, cerita kehidupan, dan wawancara.

Penelitian ini adalah studi kasus eksplorasi dan sampel yang dipilih menggunakan metode purposive sampling. Dalam penelitian kualitatif, teknik purposive sampling adalah metode yang digunakan untuk mencapai tujuan tertentu. dalam penelitian ini karyawan yang bekerja selama masa pandemi ini sebagai informan yang berusia 26-35 tahun. Tidak ada batasan jumlah responden untuk membuat sampel purposive, asalkan informasi yang diinginkan dapat diperoleh dan dihasilkan (Salain et al., 2020). Semua wawancara, dengan izin dan persetujuan para narasumber, direkam secara audio dan kemudian ditranskrip secara verbal.

\section{Hasil dan Pembahasan}

Dalam penelitian ini menggunakan teknik wawancara sebanyak 5 orang terhadap karyawan Astra Credit Companies (ACC) Cabang Bekasi. Wawancara terhadap para karyawan Astra Credit Companies adalah pemegang jabatan penting. Pada penelitian ini para informan akan diberikan Inisial K1 sampai dengan K5 untuk memudahkan penulisan.

Tabel 1

Informan Karyawan ACC Bekasi

\begin{tabular}{ccccc}
\hline Nama & Umur & Jenis Kelamin & Pendidikan & Pekerjaan \\
\hline Agus Supriadi (K1) & 28 Tahun & Laki-laki & SMA & Officer Remedial \\
\hline Ibrahim Damanik (K2) & 35 Tahun & Laki-laki & S1 & Marketing Officer \\
\hline Remo (K3) & 28 Tahun & Laki-laki & S1 & Marketing Officer \\
\hline Nadia Berliana (K4) & 29 Tahun & Perempuan & S1 & Accounting Manager \\
\hline Siti Khodijah (K5) & 35 Tahun & Perempuan & S1 & Accounting Manager \\
\hline
\end{tabular}

Berdasarkan hasil wawancara yang dilakukan oleh penulis terhadap narasumber, penulis mendapatkan jawaban yang berbeda dari setiap narasumber. Berdasarkan tanggapan responden merupakan kutipan dari hasil wawancara berdasarkan pertanyaan yang diajukan kepada narasumber. Beberapa hasil wawancara pada topik pertanyaan: 
1. Bagaimana tanggapan Anda semenjak bekerja dari rumah?

Tanggapan responden

(K1,K2,K3,dan K4) menjelaskan bahwa bekerja dari rumah selain menghemat biaya juga dapat mencegah penularan Covid-19 karena secara otomatis konsep bekerja dari rumah mengatur jarak serta interaksi dalam bekerja antara karyawan sedangkan menurut K5 menjelaskan bahwa tugas yang ia lakukan adalah bekerja di lapangan .

Tanggapan respoden berikutnya (K1,K2,dan K4) menjelaskan bahwa bekerja dari rumah dapat mengurangi tingkat mobilisasi dimana kendala utama sebelum konsep ini diterapkan dalam bekerja, responden menganggapi bahwa perjalanan untuk mencapai kantor sering terkendala kemacetan lalu lintas yang padat sehingga dengan diterapkannya konsep bekerja dari rumah dapat memberikan ketenangan pikiran dalam menyelesaikan pekerjaan.

2. Bagaimana cara perusahaan dalam menangani penumpukkan massa terhadap pelayanan public terhadap pandemic Covid-19?

Tanggapan responden (K1 dan K2) menjelaskan bahwa dalam perusahaan telah memberlakukannya jam kerja. Hal ini ditujukkan untuk mengurangi penyebaran Covid-19 di perusahaan. Berikutnya tanggapan (K3,K4,dan K5) menjelaskan bahwa pelayanan public sekarang telah tersedia di website dan via aplikasi. Jadi customer tidak perlu datang ke kantor untuk melakukan transaksi untuk melakukan pembayaran

3. Bagaimana Fasilitas pembayaran yang telah diberikan oleh perusahaan?

Tanggapan responden (K1 dan K5) menjelaskan bahwa bisa dilakukan secara online dan offline. Untuk offline bisa datang ke kantor cabang terdekat yang ditinggali kemudian bisa melakukan transaksi pembayaran. Sedangkan online, bisa melakukan transaksi pembayaran melalui mbanking dan bisa melalui supermarket terdekat.

4. Bagaimana perbedaan kinerja anda sebelum Covid-19?

Tanggapan responden K1 sampai dengan K5 menjelaskan bahwa terdepat perbedaan dimana sebelum pandemic bisa bertemu dengan customer. Sesudah Covid-19 kita tidak bisa melakukan tatap langsung ke para customer karena kami merasa takut akan tertular.

5. Bagaimana menyikapi dan meningkatkan Kinerja pada saat pandemic Covid-19

Tanggapan responden $(\mathrm{K} 1, \mathrm{~K} 3$, dan K5 menjelaskan bahwa perusahaan telah memberikan support kepada para pegawainya dengan memberikan multivitamin dan memberikan hak untuk vaksin kepada seluruh karyawan. Tanggapan lainnya (K2 dan K4) menjelaskan bahwa untuk tetap selalu menaati peraturan pemerintah yaitu dengan cara melakukan social distancing atau menjaga jarak.

Berdasarkan wawancara diatas, terdapat faktor-faktor work from home untuk menilai kinerja karyawan di masa pandemi pada karyawan Astra Credit Companies Bekasi. Berdasarkan tanggapan narasumber yang telah diajukan, penulis menemukan terdapat beberapa hal yang mempengaruhi faktor-faktor penilaian kinerja selama masa pandemi yaitu kualitas, kuantitas, waktu, penekanan biaya, pengawasan, dan hubungan antar karyawan.

Kualitas, kuantitas dan waktu saling berkaitan dengan produktifitas pekerja. Hal ini di dukung adanya pelatihan Sumber Daya Manusia terutama mengembangkan kemampuan intelektual dan kepribadian manusia guna memperoleh hasil yang maksimal dalam pengembangan karyawan baik dalam pengetahuan, keterampilan, kemampuan, sikap, dan perilaku. Kualitas, 
Kuantitas, dan Waktu dapat dijalankan dengan baik maka semakin baik pula menciptakan suasana lingkungan kerja yang baik (Ruhana, 2012).

Perusahaan memberikan hak kepada karyawan selama bekerja selalu menerapkan social distancing dan menaati protokol kesehatan yang telah diberlakukan oleh pemerintah guna membatasi penyebaran Covid di area sekitar kantor. Perusahaan juga turut memberikan hak kepada karyawan dalam ikut mesukseskan vaksinasi terhadap karyawan guna mensukseskan program vaksinasi.

Dalam halnya Hubungan antar karyawan, dukungan antar rekan kerja juga bisa mengakomodasi komunikasi dan hubungan pertemanan antar karyawan. Dukungan bisa melalui motivasi atau reward untuk memperkuat motivasi untuk memacu diri agar mencapai prestasi (Venus, 2002).

Penelitian ini sejalan dengan penelitian yang ditulis oleh (Wahyuni et al., 2021) yang menyatakan bahwa Independensi tidak berpengaruh terhadap kinerja auditor dalam situasi work from homepada Kantor Akuntan Publik di Bali. Karena semakin tinggi independensi seorang auditor dapat memberikan dampak sebaliknya sehingga kinerja auditor menurun.2)Integritas tidak berpengaruh terhadap kinerja auditor dalam situasi work from homepada Kantor Akuntan Publik di Bali. Karena semakin tinggi integritas seorang auditor dapat memberikan dampak sebaliknya sehingga kinerja auditor menurun.3)Profesionalitas berpengaruhpositifterhadap kinerja auditor dalam situasi work from homepada Kantor Akuntan Publik di Bali. Karena semakin tinggi profesionalitasseorang auditor maka kinerjayang dihasilkan seorang auditor semakin baik. 4).Obyektifitas tidakberpengaruh terhadap kinerjaauditor dalam situasi work from homepadaKantor Akuntan Publik di Bali. Semakin tinggi obyektifitas sebagai seorang auditor dapat memberikan dampak sebaliknya sehingga kinerja auditor menurun.5)Etika Profesi tidakberpengaruh terhadap kinerjaauditor dalam situasi work from homepadaKantor Akuntan Publik di Bali. Semakin tinggi etika profesi sebagai seorang auditor dapat memberikan dampak sebaliknya sehingga kinerja auditor menurun.6)Self-Efficacy berpengaruh positif terhadap kinerja auditor dalam situasi work from homepada Kantor Akuntan Publik di Bali. Karena semakin tinggi Self-Efficacyseorang auditor maka kinerja yang dihasilkan seorang auditor semakin baik. Perbedaan kedua penelitian ini jika pada penelitian sebelumnya menganalisis factor-faktor yang mempengaruhi kinerja auditor dalam situasi Work From Home, pada penelitian saat ini menganlisis faktor-faktor work from home untuk menilai kinerja karyawan. Tempat penelitian juga berbeda sehingga hasil yang diperoleh akan berbeda, kemudian jenis perusahaan yang dianalisis juga berbeda.

\section{Kesimpulan}

Kesimpulan dari konsep bekerja dari rumah (work from home) ini memiliki kelebihan dan kekurangan. Kelebihan konsep bekerja dari rumah adalah memberikan suatu kebebasan bagi karyawan untuk mengatur jam kerjanya secara fleksibel tanpa menurunkan kinerjanya dan dapat memberikan solusi untuk menghemat biaya operasional serta dampak yang terpenting adalah membatasi penyebaran Virus Covid19 melalui Social Distancing, karena secara langsung merubah kebiasaan karyawan dalam bekerja mengurangi interaksi langsung antar sesama rekan kerja. Berdasarkan hasil analisis dan pembahasan, dapat disimpulkan bahwa diterapkannya work from home tidak mempengaruhi penurunan kinerja karyawan. adanya work from home juga turut dalam efesiensi dan efektif dalam bekerja pada saat pandemi seperti biaya operasional kantor 
yang menurun, lebih fleksibel, produktivitas meningkat, dan lebih dekat dengan keluarga.

\section{BIBLIOGRAFI}

Crosbie, T., \& Moore, J. (2004). Work-life balance and working from home. Social Policy and Society, 3(3), 223233.Google Scholar

Darmalaksana, W. (2020). Metode Penelitian Kualitatif Studi Pustaka dan Studi Lapangan. Pre-Print Digital Library UIN Sunan Gunung Djati Bandung. Google Scholar

Fadrianti, F. M., \& Darmawan, E. S. (2018). Sumber daya manusia dan manajemen organisasi dalam pelaksanaan upaya kesehatan masyarakat di dua kecamatan di Jakarta Timur. Berita Kedokteran Masyarakat, 34(5). Google Scholar

Hartono, A., \& Rahadi, D. R. (2021). Work From Home Terhadap Kinerja Karyawan Pada Masa Pandemi Covid 19. Jurnal Manajemen Bisnis, 18(1), 16-21. Google Scholar

January, S. (2020). Elsevier has created a COVID-19 resource centre with free information in English and Mandarin on the novel coronavirus COVID-19. The COVID-19 Resource Centre Is Hosted on Elsevier Connect, the Company's Public News and Information. Google Scholar

Kelvyn, K., Wei, E. E., Khomali, C., Fernando, H., \& Hartanto, V. (2021). Pengaruh Work From Home Terhadap Kinerja Karyawan Di Batam. Sains: Jurnal Manajemen Dan Bisnis, 13(2), 144-162. Google Scholar

Nugraheni, R., Prihatini, A. E., \& Budiatmo, A. (2014). Pengaruh standar operasional prosedur dan pengawasan terhadap kinerja pramuniaga Pasaraya Sriratu Pemuda Semarang. Jurnal Ilmu Administrasi Bisnis, 3(2), 187-195. Google Scholar
Pradiani, T. (2017). Pengaruh sistem pemasaran digital marketing terhadap peningkatan volume penjualan hasil industri rumahan. Jurnal Ilmiah Bisnis Dan Ekonomi Asia, 11(2), 46-53. Google Scholar

Pristiyono, P., Ikhlash, M., Rafika, M., \& Hasibuan, D. K. (2020). Implementasi Work from Home terhadap Motivasi dan Kinerja Dosen di Indonesia. Jurnal Akuntansi, Ekonomi Dan Manajemen Bisnis, 8(2), 263-269. Google Scholar

Putri, P. C., \& Jumadi, S. S. (2020). Analisis Spatio-Temporal COVID-19 di Indonesia Bulan Maret-April. Universitas Muhammadiyah Surakarta. Google Scholar

Ruhana, I. (2012). Pengembangan kualitas sumber daya manusia vs daya saing global. PROFIT: Jurnal Administrasi Bisnis, 6(1). Google Scholar

Salain, P. P. P., Adiyadnya, M. S. P., \& Rismawan, P. A. E. (2020). Studi eksplorasi dampak work from home terhadap kinerja karyawan di masa pandemi Covid-19 pada bumn di wilayah Denpasar. Jurnal Ilmiah Satyagraha, 3(2), 19-27. Google Scholar

Venus, A. (2002). SDM Komunikasi di Era Kompetisi Global. Mediator: Jurnal Komunikasi, 3(2), 273-278. Google Scholar

Wahyu, A. M., \& Saâ, M. (2020). Produktivitas Selama Work From Home: Sebuah Analisis Psikologi Sosial. Jurnal Kependudukan Indonesia, 53-60. Google Scholar

Wahyuni, P. T., Sunarsih, N. M., \& Munidewi, I. A. B. (2021). Analisis Faktor-Faktor Yang Mempengaruhi Kinerja Auditor Dalam Situasi Work From Home Pada Kantor Akuntan Publik di Bali. KARMA (Karya Riset Mahasiswa Akuntansi), 1(2), 713-721. Google Scholar 


\section{Copyright holder :}

Julio Immanuel (2022).

First publication right :

Jurnal Syntax Transformation

This article is licensed under:

(cc) (i) (?) 